\title{
Continuiteit in de medische sociologie
}

Citation for published version (APA):

van Eijk, J. T. M. (2000). Continuiteit in de medische sociologie. Maastricht University. https://doi.org/10.26481/spe.20000630je

Document status and date:

Published: 30/06/2000

DOI:

10.26481/spe.20000630je

Document Version:

Publisher's PDF, also known as Version of record

\section{Please check the document version of this publication:}

- A submitted manuscript is the version of the article upon submission and before peer-review. There can be important differences between the submitted version and the official published version of record.

People interested in the research are advised to contact the author for the final version of the publication, or visit the DOI to the publisher's website.

- The final author version and the galley proof are versions of the publication after peer review.

- The final published version features the final layout of the paper including the volume, issue and page numbers.

Link to publication

\footnotetext{
General rights rights.

- You may freely distribute the URL identifying the publication in the public portal. please follow below link for the End User Agreement:

www.umlib.nl/taverne-license

Take down policy

If you believe that this document breaches copyright please contact us at:

repository@maastrichtuniversity.nl

providing details and we will investigate your claim.
}

Copyright and moral rights for the publications made accessible in the public portal are retained by the authors and/or other copyright owners and it is a condition of accessing publications that users recognise and abide by the legal requirements associated with these

- Users may download and print one copy of any publication from the public portal for the purpose of private study or research.

- You may not further distribute the material or use it for any profit-making activity or commercial gain

If the publication is distributed under the terms of Article $25 \mathrm{fa}$ of the Dutch Copyright Act, indicated by the "Taverne" license above, 


\section{De hulpverlening in de spagaat tussen autonomie en afhankelijkheid}

Jacques Th.M. van Eijk

Inaugurele rede

In verkorte vorm uitgesproken bij de aanvaarding van het ambt van Hoogleraar Medische Sociologie.

30 juni 2000

door

Prof.dr. J.Th.M. van Eijk 



\section{De hulpverlening in de spagaat tussen autonomie en afhankelijkheid}

\section{Inleiding}

In het najaar van 1998 werd ik uitgenodigd te verschijnen voor de sollicitatiecommissie ten behoeve van de vacante leerstoel Medische Sociologie. Van deze commissie maakte, zoals gebruikelijk ook een student deel uit. Uiteraard werden er de gangbare vragen gesteld over mijn wetenschappelijke prestaties en managementervaring. Het student-lid van de commissie stelde vragen van een geheel andere orde, maar zeker niet van minder belang. Begrijpelijkerwijze gingen haar vragen primair over het aandeel van de Medische Sociologie in de opleiding. Zo kan ik mij herinneren dat de betreffende studente mij de vraag voorlegde: "Als ik straks als medicus te werk gesteld ben, wat heb ik dan bij de uitoefening van mijn vak aan de medische sociologie." Ik kan u zeggen dat ik met het antwoord op deze op zich zelf voor de hand liggende vraag. behoorlijk wat moeite had. Ik meen mij te herinneren dat ik iets mompelde van "de plaats van de zieke in diens sociale context. Ondat ik het als een noodzaak zie voor een opleiding als de geneeskunde wetenschappelijke abstracties concreet hanteerbaax te maken voor het dagelijks handelen wil ik vandaag, nu ik er wat meer over heb kunnen nadenken, een poging wagen een wat specifieker antwoord 
te geven op de destujds gestelde wraag. Zoals de titel al aangeeft zall dat antwoord te maken hebben met de gerelateerde kwesties van autonomie en afhankelijkheid. Ik heb niet de pretentie dat ik een definitief antwoord kan geven. Immers de gezondheidszorg is sterk in ontwikkeling en mogelijke antwoorden op de gestelde vraag resoneren mee met deze veranderingen.

De hulpverlening van vandaag verkeert om diverse redenen in een moeilijke positie. Vergrijzing en de resulterende toename vari het aantal mensen met een chronische aandoening hebben het dillemma van de kewze tussen bevordering van autonomie en professionele dominantie prominent op de agenda gezet. Dat dilemma is niet nieuw. Immers de arts-patient-rellatie is een klassiek thema binnen de Medische Sociologie. Relatief nieuw zijn wel huidige opvattingen over autonomie in de hulpverlening.

In mijn oratie wil ik ingaan op enkele woor het thema relevante demografische veranderingen en daaraan gerelateerde veranderingen in het morbiditeitpatroon. Daarnaast zal ik kort enkele ontwikkelingen binnen de gezondheidszorg behandelen. Deze veranderingen drukken de hulpverlening als het ware verder in zijin benarde positie, waardoor respect voor autoriomie in het gedrang kan komen.

Als de hulpverlening door alle veranderingen onvoldoende toe kan komen aan de geëigende zorg voor chronisch zieken, is de vraag aan de orde welke rol chronisch zieken zelf kunnen spelen bij het zoeken van de optimale balans tussen autonomie en afhankelijkheid. Eerr mogelijkheid daartoe is zelfmanagement. De ontwikkelingen op dat terrein zal ik kort de revue laten passeren. Ten slotte zal ik aangeven hoe ik aan die ontwikkeling als medisch socioloog een bijdrage denk te kunnen leveren.

\section{Autonomie en afhankelijkheid: een plaatsbepaling}

Het begrip autonomie heeft in de medische ethiek de afgelopen decennia de nodige ontwikkeling doorgemaakt. Gold vroeger het Hippocratische adagium van "weldoen desnoods zonder de patiënt of zelfs tegen diens wil", vanaf 
de jaren 60 was het gedaan met het paternalisme. De ontwrikkeling van de medische technologie zorgde voor nieuwe ethische dilemma's toen het mogelijk werd het leven kunstmatig te verlengen. De paternalistische dokter moest plaats maken voor de dokter met respect voor de autonomie van de patiënt.

Autonomie wordt opgevat als de onafhankelijkheid van patiënten bij beslissingen over wat er met hun gezondheid gebeurt. Autonomie is het recht om te kiezen zonder inmenging. Dat kan variëren van de zelfstandigheid bij de beslissing tot het inroepen van hulp tot het zelfstandig kunnen bepalen of een preventieve, diagnostische of therapeutische (be)handeling wordt ingezet. Het betreft met andere woorden de intentie en het verrnogen om te reflecteren op de keuzes die mogelijk zijn ten aanzien van het voorkómen of oplossen van een gezondheidsprobleem door de patiënt zelf (1). Het gaat daarbij niet primair om de inhoud van de uiteindelijke beslissing zelf maar om de manier waarop die tot stand komt. Het ontbreken van autonomie impliceert in deze opvatting afhankelijkheid van anderen bij beslissingen over keuzes. Zo kan er in het geheel geen sprake zijn van autonomie in geval van wilsonbekwaamheid of bewusteloosheid en is er dus sprake van volledige afhankelijkheid. Deze opvatting van autonomie geldt in onze samenleving als een werworven recht dat als zodanig ook in de wetgeving is terug te vinden en het is dan ook bijvoorbeeld een belangrijk element bij de beoordeling van de gang van zaken bij beslissingen rond het levenseinde (2). Het respecteren van autonomie houdt voor de hulpverlener in dat deze niet intervenieert in de besiuitvorming van de patient ten aanzien van de te maken keuzes, Uiteraard wordt de patiënt krachtens zijn recht volledig voorgelicht maar de uiteindelijke beslissing ligt bij de patiënt, die een welloverwogen beslissing neemt. Uitgangspunt is de rationaliteit en het recht op individuele keuzevrijheid (3). Er wordt in dit verband ook wel gesproken van negatieve vrijheid. Inperking van deze vrijheid leidt tot zijn tegenpool nl. afhankelijkheid(4). Patienten wordt in deze opvatting geen strobreed in de weg gelegd bij het kiezen van het te volgen beleid. 
Dat in een situatie waarin er medisch gezien weinig wirist meer te behalen is (bijv. un de terminale fase), beslissingen over behandeling primair bij patiènten en hun naasten worden gelegd, ligt uiteraard woor de hand. lets ingewikkelder wordt het indien een hulpverlener te maken heeft met een patiënt die zich wenst te ontrekken aan professionele zorg als er medisch gezien wel degelijk iets geboden kan worden. Nog lastiger wordt het als het zich ontrekken aan behandeling onderdeel van het gezondheidsprobleem is, bijy in gevall van een depressieve patiënt met hartfalen die weigert het medisch regiem te volgen. De arts heeft in dat geval immers een goede behandeling voor de depressie beschikbaar waarvan de kans op resultaat vrij groot is. Behandeling van de depressie kan vervolgens tot betere therapietrouw leiden die weer een positief effect heeft op de algehele gezondheidstoestand. Moet deze patient dan maar aain zijn lot overgelaten worden, omdat het nu eenmaal zijn eigen keuze is? In de ethiek heeft dit dilemma tot een herinterpretatie van het begrip autonomie geleid (5). Als een patiënt vanuit de hulpverlener gezien onvoldoende rekening houdt met de gevolgen van onttrekking aan behandeling, kan de hulpverlener ingrijpen met het doel de consequenties van onttrekking aan de orde te stellen en de patiënt in een soort onderhandelingsproces te overtuigen van de noodzaak tot behandeling. Uiteraard vereist dit nogal wat "negotiating skills" van hulpverleners. In dergelijke gevallen doet de hulpverlener zijn best om in interactie met de patiënt te komen tot een hulpverleningsplan dat er toe moet leiden dat de gezondheid van de patiënt verbetert. Dit op zijn beurt vergroot de magelijkheid de autonomie te herstellen. In de ethiek wordt in dit verband gesproken van positieve vrijheid. Anderen, zoals hulpverleners of mensen wit de primaire omgeving, zetten zich in voor bevordering van de autonomie van de patiënt. In deze opvatting gaan afhankelijkheid en autonomie dus hand in hand.

Autonomie krijgt nu immers alleen vorm in relatie met de inzet van anderen. De herinterpretatie van het autonomie begrip heeft geleid tot het inzicht dat artsen op grond van hun professionele voorsprong de keuzen van de patiënt kunnen trachten te beinvloeden met als doel de voorwarden te scheppen voor herstel van autonomie. Deze 
opstelling wordt opgevat als een manier om de autonomie van patienten te respecteren. Het is evident dat al te sterke overtuigingskracht al snel op paternalisme kan gaan lijken. Het verschil met een patemalistische opstelling zit hem echter in de interactieve component die in het biygestelde autonomie begrip ligt opgesloten. Immers een besluit komt in samenspraak tot stand.

In de nieuwe opvatting van autonomie gaat het derhalve niet alleen om een andere manier van beslissen, het gaat ook om wat besloten wordt. Dat betreft beslissingen over de zorg voor lichamelijke, geestelijke en sociale functies van de zieke, dus over de wijze waarop de functionele autonomie bevorderd wordt. Behoefte aan deze zorg impliceert per definitie uiteraard ook afhankelijkheid van personen uit de omgeving, zoals familie of de hulpverlening. De professionele hulp is daarbij primair gericht op de vermindering van deze afhankelijkheid en zo mogelijk bevordering of behoud van de functionele autonomie. Bij beslissingen over de te leveren zorg kan het accent op elk van de genoemde functies komen te liggen en niet uitsluitend op het fysieke element. zo kan in het geheel van aanpassingen die lemand met een chronische ziekte in het dagelijks leven moet maken, het accent komen te liggen op het leren omgaan met de ziekte in het dagelijks leven (gezin, werk). Welke zorg geleverd wordt is een uitonderhandeld compromis tussen hetgeen medisch wenselijk is en datgene wat nodig is voor een nieuwe balans in een lever met chronische ziekte.

De wijze waarop recht wordt gedaan aan het principe van respect voor autonomie is sterk van invloed op de aard van de relatie tussen betrokkenen. Zo kan de bereidheid van patiënten mee te werken aan maatregelen om het gezondheidsprobleem aan te pakken sterk negatief beinviloed worden door een al te paternalistische opstelling. (6) Niet voor niets laat een meta-analyse zien dat de bereidheid van chronisch zieken om mee te werken aan het medisch regiem zeker geen vanzelfsprekendheid is (7).

De herijking van het autonomiebegrip biedt cok vanuit medisch-sociologisch perspectief een interessante 
mogelijkheid om de besiuitvorming over de zorg aan chronisch zieken op een eigentijdse wijze inhoud te geven. In eer aantal opzichten heeft de arts eem professionele voorsprong op patiénten op grond van zijn medische kennis en ervaring, aan de andere kant zijn juist chronisch zieken zelf het best in staat de consequenties van hun ziekte en het medisch regiem voor het dagelijks leven te doorzien, ja zelfs aan den lijve te ervaren. De weging van die consequenties is afhankelijk van uiteenlopende voorkeuren van patiënten, de aard en de fase van de chronische ziekte.

\section{Demografische ontwikkelingen}

De huidige demografische ontwikkelingen hebben niet alleen een sterke invloed op de workload in de gezondheidszorg, maar ook op de aard van het morbiditeitpatroon.

\subsection{De levensverwachting}

Zoals bekend is de levensverwachting de afgelopen jaren toegenomen. Op dit moment bedraagt de levensverwachting van manneri en vrouwen bij de geboorte resp. 75,1 en 80,5 jaar (8). In ongeveer 40 jaar is dat een stijging van resp. 4 en 5 jaar. De stijging van de levensverwachting is vooral te danken aan terugdringing van de kindersterfte en de bestrijding van met name infectieziekten vóor 65 -ste levensjaar. Dat blijkt uit het feit dat de levensverwachting bij 65 jaar de afgelopen 40 jaar veel minder gestegen is: voor mannen eigenlijk nauwelijks en voor vrouwen drie jaar. Opmerkelijk is dat zowel in de levenswerwachting bij geboorte als op 65-jarige leeftijd vanaf 1990 een zekere stabilisatie optreedt.

Volgens berekeningen van het RIVM heeft de ongezonde leveinsverwachting (aantal jaren van je leven met ongezondheid) gelijke tred gehouden met de levensverwachting. Dit betekent dus dat de jaren die aan het leven zijn toegevoegd in ongezondheid worden doorgebracht. Daamaast stijgt het $\%$ ouderen vanwege de geboortegolf met ongeveer $25 \%$ in de komende 15 jaar (9). De lkomende jaren zal er dus als gevolg van de hogere levensverwachting en de toename van het aantal $65+$ ers een forse toename van het aantal personen met een chronische aandoening plaats vinden die 
gedurende een langere periode van het leven in ziekte doorbrengen. Niet alleen omdat de levensverwachting is toegenomen, maar ook omdat chronische ziekten steeds eerder zullen worden opgespoord. Van de belangrijkste chronische aandoeningen wordt een toename verwacht van $25-60 \%$ (10).

De gezondheidszorg wordt dus de komende jaren met meer chronische chronisch zieken geconfronteerd die ook nog over een langere periode ziek zullen zijn. Ervan. uitgaande dat de herijking van het autonomie begrip bij uitstek van toepassing is op de zorg voor chronisch zieken zullen de kwesties van autonomie en afhankelijkheid in de nabije toekomst veel sterker dan voorheen op de voorgrond komen te staan.

\subsection{Kenmerken van acute en chronische ziekten}

In de opleiding tot arts ligt het accent veelal nog steeds primair op een benadering van gezondheidsproblemen die het best past bij acute ziekten. Hetzelfde geldt voor de medische praktijk. Het accent ligt primair op het stellen van de diagnose, uitsluiten van ernstige ziekte en curatieve of symptoombestrijdende handelingen. Dit houdt vaak in dat pas handelend wordt opgetreden als de patient aan het loket verschijnt. De behandeling van patiënten met een chronische aandoening is gebaat bij een hele andere benadering. Maar artsen hebben te weinig geleerd om te differentiëren tussen een benædering welke past bij acute dan wel chronische aandoeningen. Het is dus van groot belang de verschillen tussen acute en chronische ziekten in het dagelijks handelen te verdisconteren. 
Schema 1

Verschillen tussen acute en chronische aandoeningen

Kenmerken Acute ziekten Chronische ziekten

$\begin{array}{lll}\text { beloop } & \text { kort } & \text { lang } \\ \text { oorzaak } & \text { belkend } & \text { onbekend } \\ \text { theraple } & \text { bekend } & \text { onbekend } \\ \text { follow-up } & \text { NVT } & \text { belangrijk } \\ \text { prognose } & \text { pos } & \text { neg } \\ \text { beleving } & \text { pos } & \text { neg }\end{array}$

Over oorzaak, beloop en therapie van infectie- en acute ziekten is relatief veel bekend. Bij chronische aandoeningen ligt dat anders. Van de meeste chronische ziekten is redelijk goed bekend wat het beloop is, maar ten aanzien van de therapie staat de geneeskunde veelal machteloos. In het beste geval is het mogelijk het ziekteproces af te remmen. Wel is bekend dat leefstijlfactoren mede een belangrijke rol spelen bij het ontstaan en het beloop van chronische ziekten, maar verandering van leefstijl ligt vanwege de sterke verankering in de sociaal-culturele context meestal buiten het directe bereik van de geneeskunde. Bij acute ziekten is een goede follow-up in de zorg en anticipatie op veranderingen in het beloop uiteraard veel minder aan de orde dan bij chronische ziekten. Zorg woor chronisch zieken impliceert per definitie een longitudinale/pro-actieve benadering. De ziekte-episode bestrijkt een lange periode en vereist voor adequate actie een longitudinaal beeld van hoe de ziekte zich ontwikkelt. Dit is alleen mogelijk als patiënten met een vaste regelmaat aan het loket van de hulpverlening verschijnen. Zonder die regelmaat komen chronisch zieken vaak pas op het spreekurur als het echt mis gaat met de gezondheid. Een meer op de longitudinale benadering en tijdige detectie toegespitste handelwijze kan bij verschillende chronische aandoeningen tot een mitigatie van het ziekteproces leiden en daarmee tot een afremming van de beperkingen in de functionele autonomie (11). Uiteraard is er ook per definitie meestal een belangrijk yerschil in prognose tussen acute en chronische aandoeningen. Vanwege de beschikbare therapieen is die bij acute 
ziekten vaak gunstig. Bij chronische ziekten kan het ziekteproces in het gunstigste geval afgeremd worden. Ten slotte is de emotionele beleving van het ziek zijn een ander belangrijk verschil tussen chronische en acute ziekten. Voor mensen met een acute ziekte is er waak hoop op snelle verbetering, terwijl chronisch zieken het woonuitzicht van een vernauwend levensperspectief hebben. Het voortdurend hervinden van een evenwicht met het voortschrijden van het ziekteproces en daaraan gerelateerde veranderingen in. de levensomstandigheden leidt vaak tot gevoelems van neerslachtigheid en depressie. Uit studies onder thuiswonende ouderen blijkt bij herhaling dat een aanzienlijk percentage van de ouderen met chronische ziekten relatief vaak depressieve werschijnselen heeft. Dit percentage ligt nog aanmerkelijk hoger als er sprake is van co-morbiditeit (meer dan één chronische ziekte). De laatste jaren wordt bovendien steeds duidelijker dat depressieve verschijnselen bij ouderen een eigen directe invloed op de gezondheid hebben (12). Zo is er een lineair verband aangetoond tussen de ernst vam depressieve verschijnselen en mortaliteit (13). Depressie verhoogt de kans cardiovasculaire mortaliteit aanzienlijk. Dit geldt niet alleen woor ouderen met (risico's op) cardiovasculaire morbiditeit, maar evenzeer voor ouderen zonder deze risico's (14). Hiervoor worden onder meer pathofysiologische veranderingen als gevolg van de depressie verantwoordelijk gehouden (15-17). Een andere mogelijke verklaring is gevonden in de relatief ongezonde leefstijl van depressieve personen, hetgeen bij chronisch zieken kan resulteren in een gebrekkige therapietrouw (18). Deze gegevens maken duidelijk dat in de hulpverlening aan chronisch zieken aandacht voor het emotionele aspect van het chronisch ziek zijn dient te worden ingeruimd.

Bij de 6 genoemde kenmerken bestaat er dus een verschil tussen acute en chronische aandoeningen. In het kader van mijn betoog is het verschil tussen chronische en acute ziekten wat betreft de mogelijkheden om de autonomie te respecteren, wellicht van nog groter belang. Bij acute ziekten is er per definitie relatief weinig ruimte voor reflectie. Bij een hartinfarct moet er doorgaans acuut gehandeld worden. Er zijn geen alternatieven voor onmiddelijke 
inzet van de professionele deskundigheid. Bij chronische ziekten ligt dat uiteraard anders. Het gaat dan immers om een blijvende en voortschrijdende ziekte, met een voor ouderen vaak geleidelijk aan afnemend levensperspectief, met voldoende tijd voor een goede afweging van de behandelingsaltematieven. Gegeven de kenmerken is de herijking van het autonomiebegrip bij uitstek aan de orde bij mensen met chronische ziekten. Vanuit de Medische Sociologie is overigens al veel eerder vastgesteld dat bejegening van patiënten mede afhankelijk is van de aard van het gezondheidsprobleem (19).

\subsection{Fasen in het beloop}

Gegeven de verschillende rol van hulpverleners in de verschillende fasen van het ziekteproces is het van belang ook te kijken naar de fasen in het beloop van een chronische ziekte. Chronische ziekten kunnen aanzienlijk verschillen wat betreft het begin (acuut of geleidelijk), het beloop (progressief, met exacerbaties of constant), de gevolgen (meer /minder invaliditeit, meer/minder last) en de mate waarin het leven bedreigd wordt. Deze verschillen in aanmerking genomen biedt het volgende schema (20-21) enig inzicht in de fasen in het beloop die bij elke chronische ziekte in meerdere of mindere mate en vroeger of later een rol spelen:

\section{Schema 2}

Fasen in het beloop van chronische ziekten

Crisis:

prediagnostische fase

diagnose

acceptatie fase

Chroniciteit:

stabilisatie fase

progressie fase

complicatie fase

Terminaal stadium: preterminale fase overlijden postterminale fase 
De ontdekking van een chronische ziekte is doorgaans een persoonlijke crisis die ook de primaire orngeving niet onberoerd laat. Is de diagnose eenmaal vastgesteld dan moet de chronisch zieke gaan leren leven met (de gevolgen van) de chronische ziekte en zal een nieuwe balans moeten worden gevonden.

In de fase van chroniciteit treedt aanvankelijk een stabilisatiefase in waarin geleidelijk aän een manier van leven met de chronische ziekte dient te worden gevonden. Vaak kan er voor langere tijd een balans gevonden worden. Er za] echter een moment aanbreken waarop progressie in het ziektebeeld optreedt met verergering van de klachten. In deze fase neemt de afhankelijkheid van medische en andere hulp toe. Uiteindelijk zullen er complicaties van de ziekte optreden of co-morbiditeit. Er is doorgaans een sterker appel op medische hulp, maar ook de afhankelijkheid van de primaire omgeving is sterk toegenomen. Patiënten zijn steeds meer gebonden aan huis, stoel of bed.

De laatste levensfase dient zich aan. In deze fase die overigens qua tijdsduur aanzienlijk kan verschillen tussen patiënten met verschillende en dezelfde chronische ziekte, wordt sterk geanticipeerd op hetgeen komen gaat, en zijn patiënten vaak bezig met het naderend levenseinde.

Desondanks is het overlijden zelf woor de directe omgeving een zeer emotionele fase, waaraan door de meest betrokken hulpverleners ook na het overlijden nog de nodige aandacht wordt besteed.

In alle fasen van het beloop van een chronische ziekte speelt respect voor autonomie een belangrijke rol, zij het met verschillende accenten. Met een geleidelijke afname van de lichaamsfuncties komt het accent van de hulpverlening steeds meer te liggen op de psychische en sociale aspecten Medische zorg wordt palliatie. Met een toename van de medische mogelijkheden wordt de lengte van de ziekteepisode opgerekt en zal de bemoeienis van hulpverleners zich dus over een langere ziekte-periode gaan uitstrekken. Dit geldt a fortiori woor hulpvragen en behoeften van patiënten in de complicatie- en de terninale fase. 


\section{Ontwikkelingen in de gezondheidszorg}

Everals in de samenleving als geheel voltrekken zich op dit moment ook in de gezondheidszorg in rap tempo ingrippende veranderingen. In het bestek van deze oratie zal ik mij moeten beperken. Dat de keuze op de 3 volgende onderwerpen is gevallen is toevallig.

\subsection{Ontwikkelingen in de informatietechnologie}

We maken op dit moment een srielle ontwikkeling van de informatietechnologie door. De verwachtingen zijn hoog gespannen. Ten aanzien van de zorg voor chronisch zieken is er zowel voor patiënten als hulpverleners belangrijke winst te boeken (22). De hulpverlener zal via automatische gegevens vastlegging (Elektronisch Medisch Dossier) veel beter in staat zijn het beloop van chronische ziekten in kaart te brengen dan tot nu toe. Dat heeft het belangrijke voordeel dat bij mensen met een chronische ziekte veel gemakkelijker pro-actief te werk gegaan kan worden. Ook is hij/zij veel beter in staat hiaten in de follow-up kontakten met zijn patiënten te signaleren en mogelijke noncompliance op te sporen. De techniek is er, maar geautomatiseerde data-opslag vereist een vorm van systematisch werken die veel hulpverleners zich nog eigen moeten maken. Van veel chronische ziekten zijn inmiddels richtlijnen voor diagnostiek, behandeling en follow-up door de betreffende beroepsgroepen vastgelegd. Omdat zij de professionele standaard vertegenwoordigen zall het format van de data-opslag dezelfde structuur krijgen. Hulpverleners worden door de geautomatiseerde vastlegging als het ware in het keurslijf van het protocol geperst. Dit vereist een behoorlijke gedragsverandering.

In de gevorderde fasen van het beloop zijn vandaag de dag diverse hulpverleners bij de hulpverlening betrokken. Zo heeft een patiënt met diabetes in de fase van complicaties soms wel met meer dan 6 verschillende hulpverleners te maken. Met de huidige internet toepassingen is het technisch mogelijk om de data van alle betrokken hulpverleners automatisch in het elektronisch dossier van de relevante hulpverlener terecht te laten komen, waardoor deze voortdurend overzicht heeft over de diagnostiek en 
behandeling wan alle bij de hulpwerlening betrokkenen. Aanshiting tussen de databestanden wait verschilende hulpvenleners op elkaar impliceert dat ook alle andere betrokken hulpwerleners of instanties die woor de zorg relevante data genereren dezelfde gedragsverandering moeten doomaken. Daarbij is het nog maar de vraag hoe de samenwerking en de overeenstemming over de takkverdeling tussen alle betrokkenen er uitziet. Met andere woorden: de organisatie van zorg dient op orde te zinn, met een heldere taakverdeling tussen alle betrokkenen en daarvan afgeleid: afspraken over informatie die uitgewisseld dient worden. Alle betrokkenen zullen onderdeel van een siuitend systeem dienen te zijn. Pas dan kunnen de technische mogelijkheden gevaluteerd worden.

Met behulp van internet kunner patiënten beter geinformeerd worden over hun ziekte of klachten. Een van de doelstellingen is patienten cen betere rationele afweging voor een bezoek aan de hulpvertener te laten maken, in de hoop dat onnodige kontakten vermeden worden. Maar wat is een onnodig contact indien het gaat om een pateuent met een chronische aandoening. Het gaat hierbij doorgaans immers niet (alleen) om behoefte aan informatie, maar vooral ook om behoefte a an begeleiding. In het algemeen zal de patient van de toekomst doorgaans beter geinformeerd de spreekkamer binnenstappen en daardoor ook over meer medische kennis over de ziekte beschikken.

Informatietechnologie kan de kwaliteit en de doelmathgheid van de hulpverlening aanzitenlijk verbeteren, maar de noodzakelijke omslag zal een forse inspanning en voorbereiding van betrokken hulpverleners vergen. Dit verhoogt de bestaande druk op de ketel extra. Het keurslijf van een gestructureerde benadering die bij het gebruik van geautomatiseerde dataopslag hoort, zet het streven naar een gedifferentieerde zorg voor de patiënt in de periode vant de omslag onder druk. Patiënten zullen beter geïformeerd worden over hun ziekte.

\subsection{De fragmentatie van de zorg}

Transmurale zorg, substitutie, practice redesign, costw containment, ketenzorg, zlekenhuisverplaatste zorg. 
thuiszorgtechnologie, managed care en diseasemanagement zijn verschillende benamingen voor pogingen om de zorg te verbeteren, doelmatiger te maken en tegelijkertijd dichter bij de mensen thuis te brengen. Uiteraard zijn het ook pogingen om te anticiperen op het nog steeds toenemende aanbod van gezond heidsproblemen (23), bij een groeiend tekort aan hulpverleners.

In de huidige gezondheidszorg valt een tendens te bespeuren om de oplassing voor de problemen in de gezondheidszorg te zoeken in toenemende differentiatie en specialisatie, buiten en naast de reguliere gezondheidszorg om. Het duidelijkste voorbeeld hiervan is te zien in de Amerikaanse gezondheidszorg, waar alle potentiele aanbieders van zorg, zoals bedrijven, farmaceutische industrie en ziektekostenverzekeraars zich betrekkelijk vrij op de markt van de gezondheidszorg kunnen bewegen. Deeltjes zorg voor dezelfde chronisch zieken worden door steeds meer verschillende hulpverleners of instanties aangeboden. Meestal hebben deze innovaties betrekking op de zorg in de stabiele fase van het ziekteproces. Het blijkt dat interventiestudies bij herhaling demonstreren dat gefragmentariseerde zorg in termen van medische uitkomsten en kwaliteit van leven effectief is voorzover het deel van de zorg omvat waarop de interventie betrekking heeft. Bij al deze succesvolle experimentele verbeteringen van de zorg komt de reguliere zorg, ook na afloop van het experiment, vaak buiten schot te staan, doordat bij de experimenten betrokken hulpverleners die taak overnemen van de reguliere zorgverleners, ook na afloop van het experiment. Pas in de fase van complicaties en verergering van de ziekte vallen patiënten veelal terug op hun oude vertrouwde "primary care givers". Deze primair op doelmatigheid gebaseerde innovaties die naast de bestaande hulpverlening om zijn opgezet, blijken uiteindelijk bij verergering van de ziekte niet meer te voldoen. De fragmentarisatie van de zorg leidt niet alleen tot een wreinig kosteneffectieve uitbreiding met deeltjes zorg naast de reguliere zorg, maar leidt in de fasen van verergering van het ziektebeeld bovendien tot een gemis aan vertrouwelijkheid dat zo nodig is bij toenemende afhankelijkheid (11). 
In de VS heeft de specialisatie en de daaruit woort vloeiende fragmentarisatie van de zorg de discussie aangewakkerd over de vraag of de zorg voor chronisch zieken nu primair ziekte-specifiek (elke ziekte zijn eigen specialisme) of generiek (alle ziekten behandeld door een generalist met zo nodig doorverwijzing naar specialist) zou moeten worden georganiseerd. Het idee hierachter is dat een heldere organisatie van de zorg en bundeling van alle expertise op het terrein van de betreffende chronische ziekte de zorg effectiever maakt. Hoewel er hier nog geen. Amerikaanse toestanden zijn, zien we ook in Nederland ontwikkelingen in deze richting, bijv in de vorm van ziektespecifieke centra zoals diabetescentra of de inzet van gespecialiseerde verpleegkundigen die weliswaar niet los maar dan toch wel onathankelijk van de reguliere zorg gaan opereren. Zowel wit oogpunt van kostembeheersing als van kwaliteit van zorg zijn Amerikaanse deskundigen ervan overtuigd dat deze innovaties veel beter een plaats kunnen krijgen binnen de reguliere zorg, in plats van kleinschalige ad hoc initiatieven buiten die zorg om. Dat zullen ook kleinschalige initiatieven blijven omdat hierbij veelal de steun van de "local authorities" ontbreekt en "opinion leaders" moeilijk overeenstemming kunnen krijgen over de beste reorganisatie van zorg. Hoe deze discussie hier in Nederland ook zal aflopen: bij patiënten bestaat, met name in de gevorderde fasen van hun ziekte sterke behoefte aan centrale coördinatie. De vraag is uiteraard wel of de reguliere hulpverlening deze taak, gezien de fors gestegen werkdruk zal kunnen (blijven) waamaken. Het gevaar bestaat dat bij een tekortschietende reguliere zorg, anderen dit "gat in de markt" gaan exploiteren. Ook de mogelijkheden in EG-verband tot aanbieden en ontvangen van zorg over de gremzen heen zijn in dit verband weinig hoopgevend.

Fragmentarisatie zal dus in de regel de mogelijkheden tot het opbouwen van een hulpverlener-patient relatie met respect voor autonomie beperken. Het gaat om ad hoc oplossingen woor momentaan gerezen knelpunten, die veeleer een langere termijn oplossing verdienen. 


\section{Protocollaire Geneeskunde}

De Nederiandse gezondheidszorg vertoont ten opzichte van de ons omringende landen een gunstig beeld ten aanzien wan de inspanningen om de kwaliteit van zorg toetsbaar te maken en te verbeteren. Er is een algemene instemming met het beleid om de zorg zo doelmatig mogelijk te laten verlopen en in het algemeen kan de Nederlandse gezondheidszorg als terughoudend bestempeld worden. Niet voor niets worden in Nederland in vergelijking met overige westerse landen nog steeds relatief weinig geneesmiddelen voorgeschreven. Ook wordt er veel geïnvesteerd in de ontwikkeling van richtlijnen en protocollen waarin die terughoudendheid veelal is terug te vinden. De beschikbaarheid van een algemeen geaccepteerde standaard voor adequate diagnostiek, behandeling en follow-up is wan grote waarde niet alleen voor de beroepsgroep maar ook voor patiënten. Tegelijkertija zijn er ook minstens twee kanttekeningen te plaatsen.

In de praktijk blijkt de omslag van de oude werkwijze naar werken volgens de richtlijn niet eenvoudig. Zoals met alle gedragsverandering kost het grote moeite or ingeslepen patronen te veranderen, standaard bepaald onderzoek te gaan doen, patiënten regelmatig voor controle terug te vragen, anticiperend te gaan werken. Het vereist aanpassing van de praktijkorganisatie en het verwerven van nieuwe vaardigheden voor een beleid dat deels op evidence, deels op consensus binnen of tussen beroepsgroepen gebaseerd is. Omdat richtlijnen doorgaans vooral appelleren aan effectiviteit van de behandeling/begeleiding voor het herstel van de lichamelijke functies, is er rellatief weinig ruimte voor de psychische en sociale component. Accentuering van de glycemische controle bij de diabetespatiënt laat relatief weinig ruimte voor een bredere aanpak waarin ook de psychische en sociale dimensie zijn verdisconteert.

Protocollen hebben al gauw de status de beste handelwijze te representeren bij de huidige wetenschappelijke kennis. De protocollaire richtlijnen worden daarmee verheven tot norm voor het handelen. Afgezien van het feit dat richtlijnen vaak de noodzakelijke wetenschappelijke 
basis ontberen, hebben zij ook weinig oog voor andere mogelijke keuzes dan die het protocol aangeeft. De richtlijin kan bij rigide toepassing op gespannen voet staan met het beginsel van autonomie. Immers zonder variatie en ruime tolerantiegrenzen rond de richtlijnen kan er geen sprake zijn van autonomie. Het is rekening houden met wat Ian McWhinney, een van de "founding fathers" van de Canadese Huisartsgeneeskunde noemde "The importance of being different". Protocollen zijn als het ware landkaarten die behulpzaam zijn bij het vinden van de medische weg. Maar het vinden van de weg naar een gebied is heel iets anders dan het gebied zelf kennen (24). Adequaat gebruik van richtlijnen veronderstelt derhalve flexibele toepassing die recht doet aan de verschillende behoeften en verlangens van verschillende patiënten in verschillende fasen van hun zielkte. Rigide toepassing en voorbij gaan aan de individuele verschillen tussen patiënten leidt meer dan eens tot "evidence based resistence", van expliciete weigering tot het latent verzet tegen het ingezette regiem van patiënten die zich onbegrepen voelen (7).

Rationalisatie van het medisch handelen middels protocollen verhoogt de efficiency. Dat is in een tijd van hoge werkdruk in de gezondheidszorg een groot goed. Tegelijkertijd dienen we ons te realiseren dat doelmatigheid op gespannen voet kan staan met het recht doen aan het autonomieprincipe.

\section{Selfmanagement als alternatief}

Tegen de achtergrond van de toenemende werkdruk en inzicht in het tekort schieten van de hulpverlening an chronisch zieken is de zelfmanagementbenadering als mogelijke oplossing geintroduceerd (vanuit de gezondheidszorg zelf maar ook vanuit patientverenigingen die steeds meer opkomen voor het patientenperspectief, waarvan een benadering die rekening houdt met de individuele verscheidenheid een van de peilers vormt\}. Het idee achter deze benadering is dat chronisch zieken zelf in staat zijn hun medische zorg te sturen. Daamaast ligt er voor henzelf buiten de spreekkamer een complexe taak bij 
het aanpassen van het rollenpatroon aan hun beperktere functioneringsmogelijkheden. Selfmanagement omvat dus de aansturing van de zorg voor de gezondheid, in al zijn facetten, door de patiènt zelf.

Aanvankelijk is zelfmanagement vooral een manier om patienten zelf meer bij de behandeling van hun ziekte te betrekken door ze een rol te geven bij het zelf monitoren van hun ziekte (bloedglucase rneten), zelf medicijnen te laten nemen (astma) en meer weloverwogen bezig te laten zijn met verandering van hun leefstijl. Een manier vooral om meer controle op het beloop van de ziekte te krijgen en dus mee te helpen aan verwezenlijking van de doelstelling van de arts. Het succes van zelfmanagementprogramma's wordt in eerste instantie dan ook vooral afgemeten aan het onder controle brengen van de ziekte, therapietrouw en vermindering van complicaties en ziekenhuisopnames en veel minder nog op het leren leven met een chronische ziekte.

Uit een mega-analyse (meer dan 400 publicaties) blijkt echter dat de meest succesvolle zelfmanagementprogramma"s het streven naar een gezamenlijk probleemdefinitie van hulpverlener en patiënt gemeen hebben (25). De onderzoekers formuleren de volgende kenmerken van succesvolle programma's:

1 Streven naar een gezamenlijke probleemdefinitie van patiënt en hulpverlener als uitgangspunt voor een zelfmanagement programma.

2 Het formuleren van een daarop gebaseerde doelstelling en planning om dat doel stapsgewijs te verwezenlijken.

3 Het aanbleden van zelfmanagementsupport in de vorm van trainingen en hulp bij de implementatie van het geleerde.

4 Actieve lange termijn follow-up

Met name de gemeenschappelijk onderschreven doelstelling vormt dus een wezenlijk element, omdat het tot uitdrukking brengt dat hulpverlener en patiënt gezamenlijk de ziekte trachten te managen. Ook anderen hebben dit 
als een wezenlijk element in de hulpverlening benadrukt $(26,27)$.

Tot dan toe hebben alle programma"s een ziekte-specifieke benadering, gericht op patiënten met diabetes mellitus, astma, artritis hartfalen of andere cardiovasculaire ziekten, ten teken dat het voomamelijk om initiatieven gaat die vanuit gespecialiseerde zorg werden opgezet, veelal buiten de reguliere zorg om. Baanbrekend werk is in dit verband recent gepubliceerd door een groep van de Stanford University te Palo Alto. Het idee achter de door hen voorgestane generieke benadering is dat leven met een chronische ziekte overeenkomstige consequenties heeft voor patiënten met verschillende chronische ziekten. In hun onderzoek werden patiënten geincludeerd met verschillende chronische ziekten, in verschillende fasen van het beloop, in de veronderstelling dat elke fase oprieuw om vergelijkbare adaptieve opgaven vraagt. In een grote interventie studie ( $N=952)$ wordt aangetoond dat dit zelfmanagement programma niet alleen tot aanzienlijke verbeteringen in de klassieke parameters als het onder controle brengen van de ziekte en kosten leidt, maar ook tot verbeteringen in beleefde gezondheid, validiteit en sociaal functioneren leidt (28).

De zelfmanagement benadering vormt daarmee een belangrijke aanvulling op de huidige gangbare zorg aan chronisch zieken. In deze benadering is het mogelijk recht te doen aan de autonomie van de chronisch zieke door de voorwaarden te creëren dat chronisch zieken zelf in overeenstemming met hun lichamelijke gezondheid in staat gesteld worden medisch verantwoorde eigen keuzes te maken bij de noodzakelijke aanpassingen in hun leefwereld. Blijkt een generieke benadering mogelijk, dan zal zelfmanagement ondersteuning heel goed door generalistische hulpverleners, bijwoorbeeld vanuit de thuiszorg, aangeboden kunnen worden. 


\section{Ten besluit}

Ik heb uiteengezet dat de hulpverlening zich in een lastige positie bevindt tussen respect voor de autonomie van de chronisch zieke en de professionele dominantie. Deze positie is des te lastiger in het huidige tijdsgewricht waarin de organisatie van de zorg door onderbezetting en toenemende werklast un zijn voegen kraakt. Ik heb voorbeelden genoemd van aanpassingen in de organisatie van de zorg, de ontwikkelingen op het gebied van de informatietechnologie en de protocollaire geneesikunde, die de doelmatigheid beogen te bevorderen, die alle, leder op een eigen manier de positie van de hulpverlener bemoeilijken. Factoren die de hulpverlening nog verder in zijn spagaatpositie kunnen drukken, zoals de ontwikkelingen van de medische techno-

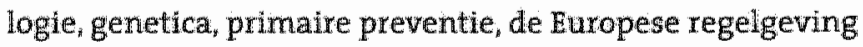
op het gebied van de gezondheidszorg, het wegvallen van mantelzorg en de toenemende heterogeniteit van onze samenleving bleven daarbij nog onbesproken. De betrokkenheid van de hulpverlener bij al deze ontwikkelingen zal concurreren met de vereiste zorg voor chronisch zieken.

Als de hulpverlening dus woorlopig in zo'n ongernakkelijke houding verkeert, moet de chronisch zieke zelf in actie komen. De chronisch zieke van de toekomst is zelfbewuster en beter geinformeerd over (de consequenties van) zijn chronische ziekte en zal beter in staat zijn voor zijn eigen belangen/behoeften op te komen. Zelfmanagement kan daarbij een belangrijke rol spelen. Het biedt de mogelijkheid de chronisch zieke een gevoel van meer grip op het leven met de beperkingen van de ziekte te geven.

In het medisch onderwijs worden studenten voorbereid op hun toekomstige taak in de gezondheidszorg. Op dit moment wordt in Maastricht het medisch curriculum her. zien. Het is geen toeval dat hierbij een betere en meer op de behoefte afgestemde verhouding tussen de aandacht voor acute en chronische ziekten wordt nagestreefd. De opleiding wordt daarbij in plaats van op ziekte meer gericht op de toekomstige arts en op de patiënt in diens sociale context. Denkend aan de vraag van de student uit mijn benoemingscommissie, hoop ik aan dit vernieuwde 
onderwijs een bijdrage te kunnen leveren door studenten in te wijden in de bestaande medisch-sociologische inzichten over de gevolgen van ziekte voor het dagelijks leven, de heel verschillende manieren waarop daarmee door patiênten en hun omgeving wordt omgegaan en de rol die hulpverleners daarin kunnen spelen. Hun aandeel in de ontwilkkeling van een zelfmanagement-attitude bij patiënten zal daarin prominent naar voren kunnen komen.

Wat betreft het onderzoek zal mijn focus vooral gericht zijn op de wetenschappelijke onderbouwing van de zorg aan chronisch zieken middels longitudinaal observationeel onderzoek naar de gevolgen van chronische ziekten voor deelname aan het sociale leven zoals gezin, werk en vrije tijd. Verder de wijze waarop patiënten met deze gevolgen omgaan als mede de sociale determinanten van de omgang met ziekte. Zelfmanagement neemt ook daarin een prominente plaats in. De medisch-sociologische benadering van de stress- en netwerktheorie gelden daarbij als uitgangspunt. Naast meer funderend onderzoek hoop ik interventiestudies te stimuleren naar het effect van selfmanagement ondersteuning op de functionele autonomie van chronisch zieken. Bij deze interventies zal zoveel mogelijk ook het gezin en de arbeidssituatie betrokken worden. De medisch-sociologische invalshoek bestaat hier vooral wit het gebruik van inzichten in relevante verschillen tussen sociale categorieën ten aanzien van de omgang met ziekte, met name bij het ontwerpen van interventies. Het spreekt vanzelf dat hiervoor ook leentje buur gespeeld zal worden bij de sociaall-psychologische theorieën over beinvloeding van gedrag. Samenwerking met medische disciplines lijkt mij bij de uitvoering van deze interventiestudies onontbeerlijk. Omdat hiermee een relatief nieuw onderzoeksveld wordt geëntameerd zal instrumentontwikkeling voor het meten van autonomie en zelfmanagement nodig zijn. Een glijdende start voor onderzoek op dit terrein is inmiddels binnen het kader van de instituten Health/Extra en de Capaciteitsgroep Zorgwetenschappen gemaakt. 
1. Pool A Autonomie, afhamkelijkheid en langdurige zorgwerlening [dissertatie], Rikswintwersitent Utrecht, 1995

2. Kuitert $H M$ Zelfododing, maral en hulpwerlering. In: Becufort ID de, Dupuis HM [red]. Haindboek Gezondheidsethiek; Van Goraun. Assen/Maastricht; 1988

3. Kuitert HM Autonomic: een lastige lautkomer in de ethiek [afscheldscollege] Vrije Universiteit, Amsterdam, 1989

4. Widdershoven GAM Autonomie in de hulpwerlening; Een herinterpretatie 1998 Tijdschrift waor de socialle sector; 1: 20-25

5. Widdershoven GAM. Ethiek in de kliniek. Hedendaagse benaderingen in de gezondheldsethiek. Boom: Amsterdam/Meppel, 2000

6. McWilliam $C_{\text {, B }}$ Brown $J B$, Carmichael $L$, Lehman IN. A new perspective on threatened autonomy: the disempowering process. Soc Sci Med 1994: $38(2): 327 \cdot 38$

7. Haymes RB, McKibbon KA, Kamani $R$. Systematic review of randamised trials to assilst patients to follow prescriptions for medications. Lancet $1996 ; 348: 383-386$

8. Perenboom RUM, Herten LM van, Boshuizen HC en Water HPA wan de. Trends in de gezonde levenswerwachting in Nederland 1983-2994, met een werdeling naar de ernst wan ongezondheid. In: Maas PIM van der, Kramers PGN. Volksgezond heid; Toekomstverkenning 1997, deel III Gezondheid en lewenswerwachting gewogen; Elsevier/ De tijdstroom. 1997

9. Wijst Twan der, Zwiers R. Zorgen over de zorg vam morgen Demas 1999: 15,7376

10. Bergh Jeths wan den $A_{\text {, Ruward }} D_{*}$ Verkley $H$. De invloed van demografische en epidemiologische antwikkelingen op het antal chronisch zieken in de toekomst. TSG 2000; 78: 75-80.

11. Wagner EH, Austin BT, Konff M won. Organizing care for patients.(1996) The Milbank Quarterly; $74511-544$ 


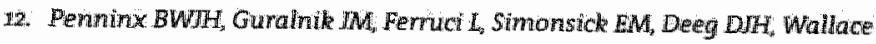
RE. Depressive symptoms and physical dechine in community dwelthy older persons. IAMA 1998; 279: 1720-1726

13. Penninx BWIH, Geerlings S, Deeg DIH, Eijk JThM van, Tilburg W" wan, Beekman ATF. The effect of minor and major depression on the risk of death in old age. Arch Gen Psychiatry 1999: 56:889-895

14. Penminx BWIH, Beekman ATF, Honig A, Deeg, DIH, Schoevers RA Eijk I TH M van, Tilburg W van. Depression and Cardiac Mortality. Results from a Community-based longitudinal study Arch Gen Psychiatry (conditionally accepted)

15. Watkins LL, Grossman P. Association of depressive symptoms with reduced baroreflex cardiac control in coranary artery disease. Am Heart 1999:37:453-457

16. Camey RM, Saunders RD, Freedland KE, stein P, Rich MW, Jaffe S. Association of depression with reduced heart rate wariability in coronary artery disease. Am 3 Cardiol $1995 ; 67: 562-564$

17. Gullette ECD, Bumenthal JA, Babyak Ma Wagh RA, Frid DJ Oçonnor $C M$, Motris J, Krantz DS. Effects of mental stress on myocardial ischemia during daily life. JAMA 1997; 277:15:21-1526

18. Camey RM, Freedland KE, Rich MW, Jaffe AS. Depression as a risk foctor for cardiac events: a review of possible mechanisms. Ann Behaw Med $1995: 17: 412-149$

19. Szasz T, Hollender M. A contribution to the philosophy of medicine: The basic models of the doctor-patient relationship. IAMA 1956, 97:585-8

20. Rolland IS. Chronic illness and the lifecycle: a conceptual framework. Family Proc 1987; 26:203-21

21. Ejh JThM wan Care for the chronically ill the future role of health carse professionals and their patients 1998. Pat Educ Couns 35:233-4013.

22. Litzelman DK, DitusME, Miller ME, Thierney WM Reguiring Physicians to respond to computerized treminders improves their compliance with preventive care protocols I of Int Med 1993; $8: 311-17$ 
23: Spreeuwenberg C Netwerken van chromisch zieken foratiel Waostricht, 1995

24. McWhininey IR. The importance of being different, $B$ IGP 1996, 46:433-436

25. Center for Adwantement of Health 1966 . Indexed Biblography of behavioral Interventions of Chronic Disease. Washington, D.C.

26. Korff M won, Gruman $I_{1}$ schaefer 1 , Cury SJ, Wagner Ed. Coilaborative Management of chronic illness. Ann Intern Med. 1997: 127: 1097-1102

27. Charles $\mathrm{C}$; Gafni $A$, Whelan T. Decisionmaking in the physician-patient encounter: revisiting the shared treatment decition making model soc Sci Med 1999:49:651-61

28. Lorig K, Sobel DS, Stewart AL, Brown BW, Bandura A, Ritter P, Gonzalez, $V M$, Laurent $D D$. Holman $H R$. Evidence suggesiting that a chronic disease self-management program cam improve health status while reducing hospitalization. Medical Care 1999: $1: 44$ 